DOI: $10.19195 / 2084-5065.43 .3$

\title{
Oszustwo szkodowe i bezszkodowe jako dwie odmiany przestępstwa oszustwa
}

\author{
MAREK BIELSKI \\ Katedra Prawa Karnego \\ Uniwersytet Jagielloński
}

Bogaty dorobek naukowy Profesora Tomasza Kaczmarka od lat pozostaje niewyczerpanym źródłem inspiracji rozważań dotyczących fundamentalnych zagadnień z zakresu nauki prawa karnego. W szczególności nieoceniony jest wkład, jaki wniosły do doktryny prawa karnego badania Jubilata nad problematyką społecznego niebezpieczeństwa czynu ${ }^{1}$, a później — społecznej szkodliwości czynu ${ }^{2}$ oraz zagadnień związanych z dyrektywami sądowego wymiaru kary ${ }^{3}$. Mając zaszczyt uhonorowania działalności naukowej Profesora Tomasza Kaczmarka z okazji ju-

1 Zob. między innymi T. Kaczmarek, Społeczne niebezpieczeństwo czynu i jego bezprawność jako dwie cechy przestepstwa, Wrocław 1966; idem, Materialna istota przestępstwa i jego ustawowe znamiona, Wrocław 1968.

2 Zob. między innymi T. Kaczmarek, Materialna treść przestęstwa jako problem kodyfikacyjny, [w:] Rozważania o prawie karnym. Księga pamiatkowa z okazji siedemdziesięciolecia urodzin Profesora Aleksandra Ratajczaka, red. J. Szwarc, Poznań 1999, s. 171 n.; idem, O próbach reinterpretacji pojęcia społecznej szkodliwości czynu w okresie przemian ustrojowych (na marginesie ksiązki Roberta Zawłockiego), [w:] Węzłowe problemy prawa karnego, kryminologii i polityki kryminalnej. Księga pamiatkowa ofiarowana Profesorowi Andrzejowi Markowi, red. V. Konarska-Wrzosek, J. Lachowski, J. Wójcikiewicz, Warszawa 2010, s. 121 n.; idem, O elementach wyznaczajacych treść społecznej szkodliwości czynu zabronionego i jej stopień (ekspozycja problemów spornych), [w:] Teoretyczne i praktyczne problemy wspótczesnego prawa karnego. Księga Jubileuszowa Dedykowana Profesorowi Tadeuszowi Bojarskiemu, red. A. Michalska-Warias, I. Nowitkowski, J. Piórkowska-Flieder, Lublin 2011, s. 133 n.; idem, Dobro prawne i społeczna szkodliwość czynu, [w:] System Prawa Karnego, t. 3. Nauka o przestępstwie. Zasady odpowiedzialności, red. R. Dębski, Warszawa 2013, s. 240 n.

3 Zob. między innymi T. Kaczmarek, Sędziowski wymiar kary w PRL w świetle badań ankietowych, Wrocław 1972; idem, Ogólne dyrektywy sq̨dowego wymiaru kary w ujęciu teorii i praktyki sądowej, Wrocław 1980; idem, Ogólne dyrektywy wymiaru kary jako problem kodyfikacyjny, [w:] Problemy reformy prawa karnego, red. T. Bojarski, E. Skrętowicz, Lublin 1993, s. 47 n.; idem, Problemy indywidualizacji wymiaru kary sprawiedliwej i celowej, [w:] Dyrektywy sadowego wymiaru kary, red. J. Majewski, Warszawa 2014, s. 9 n. 
bileuszu jego osiemdziesiątych urodzin, a jednocześnie pragnąc wyrazić wdzięczność za życzliwość, jaką Pan Profesor okazywał autorowi od początku jego pracy naukowej, chciałbym zadedykować Jubilatowi opracowanie poświęcone omówieniu znaczenia dla prawidłowego stosowania regulacji prawnokarnych okoliczności determinujących stopień społecznej szkodliwości czynu w rozumieniu art. 115 $\S 2$ k.k., które nie stanowią znamion realizowanego przez sprawcę typu czynu zabronionego, a które w świetle regulacji części ogólnej kodeksu karnego mają często równie istotne znaczenie z punktu widzenia adekwatnej i sprawiedliwej reakcji karnej na fakt popełnienia przestępstwa jak te okoliczności przedmiotowe i podmiotowe, które zostały wskazane na płaszczyźnie ustawowego opisu jako znamiona typu czynu zabronionego. W doktrynie prawa karnego niedostatecznie akcentuje się, a w praktyce wymiaru sprawiedliwości często wręcz ignoruje, znaczenie tych okoliczności, które co prawda nie mają znaczenia dla przesądzenia realizacji znamion typu czynu zabronionego, lecz mają istotne znaczenie dla ustaleń związanych ze stopniem społecznej szkodliwości czynu oraz ustaleń mających znaczenie dla wymiaru kary.

Klasycznym przypadkiem takiej okoliczności, która zazwyczaj nie jest ujmowana $\mathrm{w}$ opisie znamion typu jako samodzielne znamię przedmiotowe, a jednocześnie ma bardzo istotne, czasami wręcz kluczowe, znaczenie z perspektywy określenia stopnia społecznej szkodliwości czynu oraz wymiaru kary, jest szkoda majątkowa wyrządzona popełnionym przez sprawcę przestępstwem. Dokonanie skrupulatnych ustaleń w zakresie wysokości szkody majątkowej ma duże znaczenie zarówno z punktu widzenia determinanty stopnia społecznej szkodliwości, jaką na gruncie art. $115 \S 2$ k.k. jest rozmiar wyrządzonej lub grożącej szkody, jak i określenia adekwatnego wymiaru kary, który w związku z regulacją art. 53 $\S 2$ k.k. powinien w szczególności uwzględniać rodzaj i rozmiar ujemnych następstw przestępstwa. Ustalenia w zakresie szkody majątkowej mają również zasadnicze znaczenie z punktu widzenia takich regulacji kodeksowych, jak orzeczenie na podstawie art. $46 \S 1$ k.k. obowiązku naprawienia szkody czy skorzystanie przez sprawcę z dobrodziejstw na płaszczyźnie kary, wynikających z klauzuli dobrowolnego naprawienia szkody ${ }^{4}$.

Typem czynu zabronionego, dającym doskonałą egzemplifikację roli okoliczności mającej znaczenie dla oceny stopnia społecznej szkodliwości czynu, jaką jest zakres wyrządzonej przestępstwem szkody majątkowej w kształtowaniu sfery adekwatnej reakcji karnej, jest art. $286 \S 1$ k.k. statuujący odpowiedzialność karną za przestępstwo oszustwa. Wskazany typ czynu zabronionego stanowi interesujący przykład w kontekście prowadzonych rozważań ze względu na fakt, iż przyjmowana wykładnia jego znamion pozwala wyróżnić na gruncie przestępstwa dwie jego zasadnicze, różniące się stopniem karygodności, odmiany, jakimi są

${ }^{4}$ Klauzule dobrowolnego naprawienia szkody przewidują art. 295 k.k. lub art. 307 k.k. 
oszustwo szkodowe i oszustwo bezszkodowe. Co prawda każda z wymienionych odmian oszustwa mieści się w opisie znamion typu czynu zabronionego z art. 286 $\S 1$ k.k., lecz w istocie zasadniczo różnią się one generalno-abstrakcyjnie określonym stopniem karygodności oraz — w konsekwencji — zasługują na inną reakcję na płaszczyźnie wymiaru kary.

Powszechnie przyjmowana wykładnia znamion typu czynu zabronionego z art. $286 \S 1$ k.k. daje podstawę do sformułowania tezy, że zakres odpowiedzialności karnej za przestępstwo oszustwa jest bardzo szeroko określony na gruncie polskiego porządku prawnego ${ }^{5}$. Podstawę do postawienia takiego wniosku daje analiza poglądów przyjmowanych zarówno w doktrynie prawa karnego, jak i w orzecznictwie sądowym, opowiadających się z jednej strony za szerokim rozumieniem znamienia przedmiotowego typu czynu zabronionego z art. 286 $\S 1$ k.k., określającego skutek przestępny w postaci „,niekorzystnego rozporządzenia mieniem"6, a z drugiej strony poglądów opierających się na powszechnie przyjmowanej wykładni znamion strony podmiotowej przestępstwa oszustwa związanej z interpretacją zwrotu „,w celu osiągnięcia korzyści majątkowej”"7.

Przesądzenie realizacji znamion przedmiotowych przestępstwa oszustwa wymaga dowodowego wykazania, że sprawca doprowadził inną osobę do niekorzystnego rozporządzenia własnym lub cudzym mieniem za pomocą jednego z trzech alternatywnie, lecz enumeratywnie określonych w art. $286 \S 1$ k.k. zachowań sprawczych polegających na wprowadzeniu jej w błąd, wyzyskaniu jej błędu albo wyzyskaniu jej niezdolności do należytego pojmowania przedsiębranego działania ${ }^{8}$. Istotne znaczenie dla dalszych rozważań ma zaakcentowanie, że przestępstwo oszustwa jest zaliczane do kategorii przestępstw materialnych,

5 Zob. O. Górniok, D. Pleńska, [w:] System Prawa Karnego, t. 4. O przestęstwach w szczególności. Część II, red. I. Andrejew, L. Kubicki, J. Waszczyński, Wrocław 1989, s. 419.

${ }^{6} \mathrm{Na}$ gruncie wykładni art. $286 \S 1$ k.k. powszechnie przyjmowane jest autonomiczne rozumienie pojęcia rozporządzenia mieniem, przez które rozumie się zarówno dokonanie czynności o skutkach rzeczowych, jak i obligacyjnych, a także czynności nieuregulowane przez przepisy prawa cywilnego, lecz określone w innych dziedzinach prawa. Zob. J. Bednarzak, Przestępstwo oszustwa w polskim prawie karnym, Warszawa 1971, s. 70 n.; M. Dąbrowska-Kardas, P. Kardas [w:] Kodeks karny. Część szczególna. Komentarz, t. 3, red. A. Zoll, Warszawa 2016, s. 296 n.; O. Górniok, D. Pleńska, op. cit., s. 419; T. Oczkowski, Oszustwo jako przestępstwo majątkowe i gospodarcze, Kraków 2004, s. 61 n.; A.N Preibisz, Niekorzystne rozporządzenie mieniem jako znamię oszustwa (art. 286 \& 1 k.k.), „Prokuratura i Prawo” 2005, nr 10; L. Wilk [w:] Kodeks karny. Część szczególna, t. 2. Komentarz. Art. 222-316, red. M. Królikowski, R. Zawłocki, Warszawa 2013, s. 642. Por. A. Pilch, Oszustwo sądowe — trójkątne oszustwo, „Przegląd Sądowy” 2010, nr 1, s. 125 n.; A. Jezusek, Orzeczenie sadowe w sprawie cywilnej jako rozporządzenie mieniem w rozumieniu art. 286 k.k., „Przegląd Sądowy” 2012, nr 1, s. 55 n.

7 Zob. J. Bednarzak, op. cit., s. 96 n.; M. Dąbrowska-Kardas, P. Kardas, op. cit., s. 312 n.; T. Oczkowski, op. cit., s. 27 n.

8 Zob. M. Dąbrowska-Kardas, P. Kardas, op. cit., s. 296 n.; O. Górniok, D. Pleńska, op. cit., s. $415-418$. 
charakteryzujących się tym, iż dla przyjęcia realizacji znamion tego typu w formie dokonanej wymagane jest wystąpienie skutku przestępnego w postaci niekorzystnego rozporządzenia mieniem ${ }^{9}$. Materialny charakter przestępstwa oszustwa implikuje konieczność istnienia podstaw do obiektywnego przypisania sprawcy skutku przestępnego ${ }^{10}$ przez wykazanie związku między podjęciem zachowania sprawczego polegającego na wprowadzaniu innej osoby w błąd, wyzyskaniu jej błędu albo niezdolności do należytego pojmowania przedsiębranego działania, a w konsekwencji — doprowadzeniem do wystąpienia skutku przestępnego w postaci niekorzystnego rozporządzenia mieniem przez pokrzywdzonego. Na gruncie znamion przedmiotowych typu czynu zabronionego z art. $286 \S 1$ k.k. prawnokarnie relewantna relacja sprawcza sprowadza się do stwierdzenia, że do rozporządzenia mieniem nie doszłoby, albo rozporządzenie to miałoby inny zakres, gdyby podmiot rozporządzający mieniem nie działał pod wpływem błędu lub byłby zdolny do pojmowania znaczenia przedsiębranego działania. Najogólniej rzecz ujmując skutek przestępny w postaci niekorzystnego rozporządzenia mieniem rozumiany jest jako wystąpienie takiej, wynikającej z podjęcia przez sprawcę zachowań oszukańczych, zmiany w świecie zewnętrznym, łączącej się w świetle obiektywnych kryteriów oceny z wystąpieniem stanu bezpośredniego zagrożenia interesów majątkowych pokrzywdzonego ${ }^{11}$, który jest związany z faktem, że w wyniku takiego niekorzystnego rozporządzenia sytuacja majątkowa dysponenta mieniem jest pogorszona w porównaniu z sytuacją, jaka miałaby miejsce, gdyby do takiego rozporządzenia dokonanego pod wpływem błędu nie doszło albo rozporządzenie to miało inny zakres. Niekorzystna zmiana w sytuacji majątkowej rozporządzającego mieniem nie może być utożsamiana tylko i wyłącznie z wystąpieniem po jego stronie szkody majątkowej ${ }^{12}$. Niekorzystność rozporządzenia mieniem ma szerszy zakres znaczeniowy niż pojęcie szkody majątkowej, co sprawia, że tak określony skutek przestępny może, lecz nie musi łączyć się z wystąpieniem szkody majątkowej po stronie rozporządzającego. Do przyjęcia niekorzystności rozporządzenia mieniem wystarczające jest wykazanie, że następstwem zabiegów oszukańczych

9 Zob. M. Dąbrowska-Kardas, P. Kardas, op. cit., s. 296 n.; O. Górniok, D. Pleńska, op. cit., s. $418-419$.

${ }^{10}$ Zob. M. Dąbrowska-Kardas, P. Kardas, op. cit., s. 303-304; B. Michalski [w:] Kodeks karny. Część szczególna, t. 2. Komentarz. Art. 222-316, red. A. Wąsek, R. Zawłocki, Warszawa 2010, s. 1130-1131.

11 Zob. M. Dąbrowska-Kardas, P. Kardas, op. cit., s. 299-303.

12 Zob. J. Bednarzak, op. cit., s. 81 n.; M. Dąbrowska-Kardas, P. Kardas, op. cit., s. 300 n.; O. Górniok, D. Pleńska, op. cit., s. 419; B. Michalski, op. cit., s. 1135; T. Oczkowski [w:] System Prawa Karnego, t. 9. Przestępstwa przeciwko mieniu i gospodarcze, red. R. Zawłocki, Warszawa 2011, s. 141. Zob. też wyrok SN z dnia 30 sierpnia 2000 r., V KKN 267/00, OSNKW 2000, z. 9-10, poz. 85 z glosą aprobującą J. Satko, OSP 2001, z. 3; wyrok SA w Łodzi z dnia 29 stycznia 2001 r., II AKa 74/01, Prok. i Pr. 2002, nr 10, poz. 16; postanowienie SN z dnia 27 września 2013 r. IV KK 211/13, LEX nr 1433610; wyrok SA w Szczecinie z dnia 12 czerwca 2014 r., II AKa 65/14, LEX nr 1499031; wyrok SA w Katowicach z dnia 25 września 2015 r. II AKa 299/15 LEX nr 1950316. 
było co najmniej wystąpienie stanu bezpośredniego niebezpieczeństwa wyrządzenia szkody majątkowej, a nawet pogorszenie jego sytuacji majątkowej, związane z takimi następstwami zabiegów oszukańczych, które prowadzą do trudności w realizacji przez pokrzywdzonego swojego interesu majątkowego, albowiem dla wypełnienia tego znamienia wystarczające jest powstanie układu sytuacyjnego, w którym w świetle obiektywnej oceny interes majątkowy pokrzywdzonego zostanie zagrożony w związku z wystąpieniem po stronie dokonującego niekorzystnego rozporządzenia mieniem stanu niepewności co do jego interesu majątkowego. Niekorzystność rozporządzenia mieniem może zarówno łączyć się ze stworzeniem niebezpieczeństwa rzeczywistego uszczerbku w majątku poszkodowanego (damnum emergens), jak i prowadzić do niebezpieczeństwa utraty spodziewanych korzyści (lucrum cessans) ${ }^{13}$.

Oparcie opisu znamion przedmiotowych typu czynu zabronionego z art. 286 $\S 1$ k.k. o tak ujęty skutek przestępny zapewnia bardzo szeroką prawnokarną ochronę chronionego na gruncie tego typu dobra prawnego, jakim jest mienie w znaczeniu szerokim, to jest całokształt sytuacji majątkowej podmiotu, wyznaczanej możliwością realizowania przysługujących temu podmiotowi praw majątkowych ${ }^{14}$. Z perspektywy ochrony dobra prawnego w postaci szeroko rozumianego mienia (majątku) tak ujęte znamię przedmiotowe, określające skutek przestępny, pozwala objąć zakresem odpowiedzialności karnej za przestępstwo oszustwa zarówno zachowania, które prowadzą do naruszenia dobra prawnego $\mathrm{w}$ postaci mienia przez spowodowanie uszczerbku na mieniu związanego $\mathrm{z}$ wystąpieniem szkody majątkowej, jak i zachowania, które prowadzą do bezpośredniego narażenia na niebezpieczeństwo dla tak ujętego dobra prawnego w związku $\mathrm{z}$ wystąpieniem stanu pogorszenia sytuacji majątkowej pokrzywdzonego w porównaniu do takiej sytuacji, w jakiej znajdowałby się, gdyby nie doszło do niekorzystnego rozporządzenia mienia. Przyjmowana powszechnie szeroka wykładnia znamienia skutku przestępnego relewantnego, na gruncie art. $286 \S 1$ k.k., prowadzi do wniosku, że do niekorzystnego rozporządzenia mieniem dochodzi w sytuacji, w której na skutek zachowań oszukańczych dojdzie do wystąpienia bezpośredniego niebezpieczeństwa dla interesu majątkowego pokrzywdzonego, które może ograniczać się do wystąpienia stanu zagrożenia jego interesów majątkowych lub może doprowadzić do skutku dalej idącego, jakim jest wyrządzenie szkody majątkowej w mieniu ${ }^{15}$. Takie ujęcie pozwala zaliczyć przestępstwo oszustwa do kategorii typów z konkretnego narażania dobra prawnego na nie-

13 Zob. M. Dąbrowska-Kardas, P. Kardas, op. cit., s. 300; O. Górniok, D. Pleńska, op. cit., s. 419.

14 Zob. M. Dąbrowska-Kardas, P. Kardas, op. cit., s. 273 n., T. Oczkowski [w:] System Prawa Karnego, t. 9, s. 123.

15 Zob. M. Dąbrowska-Kardas, P. Kardas, op. cit., s. 299 n. 
bezpieczeństwo ${ }^{16}$ ze względu na fakt, iż z punktu widzenia konstrukcji znamion przedmiotowych typu czynu zabronionego z art. $286 \S 1$ k.k. wystarczające jest wykazanie, że w związku z podjęciem zachowań oszukańczych doszło do skutku w postaci bezpośredniego narażania interesów majątkowych pokrzywdzonego na niebezpieczeństwo związane z doprowadzeniem dysponenta do niekorzystnego rozporządzenia mieniem. Fundamentalne znaczenie dla prowadzonych rozważań ma to, że wyrządzenie szkody majątkowej nie należy do znamion przedmiotowych przestępstwa oszustwa ${ }^{17}$. Dokonanie przestępstwa oszustwa nie jest uzależnione od doprowadzenia przez sprawcę do skutku przestępnego w postaci naruszenia dobra prawnego poprzez wyrządzenie szkody majątkowej na mieniu.

Za szerokim zakreśleniem granic odpowiedzialności karnej z art. $286 \S 1$ k.k. przemawia również powszechnie przyjmowana wykładania znamienia podmiotowego przestępstwa oszustwa. W doktrynie prawa karnego i orzecznictwie sądowym prezentowany jest jednolity pogląd, że oszustwo zalicza się do kategorii przestępstw kierunkowych, których realizacja znamion może nastąpić tylko $\mathrm{w}$ formie zamiaru bezpośredniego ${ }^{18}$. Użyte do opisania strony podmiotowej znamię „,W celu osiągnięcia korzyści majątkowej” uzależnia odpowiedzialność karną za oszustwo od podjęcia przez sprawcę zachowań oszukańczych z intencjonalnym nastawieniem nakierowanym na polepszenie własnej lub cudzej sytuacji majątkowej, przy czym polepszenie takiej sytuacji jest rozumiane bardzo szeroko. W kontekście ustawowego opisu znamion strony podmiotowej oszustwa ważne jest zaakcentowanie dwóch kwestii. Po pierwsze — nie ma podstaw normatywnych do zawężania zachowań oszukańczych podjętych „w celu osiągnięcia korzyści majątkowej” do zachowań podjętych „,z zamiarem przywłaszczenia mienia"19. Charakterystyczną cechą opisu znamion strony podmiotowej oszustwa jest uzależnienie karalności od podjęcia zachowań oszukańczych w celu osiągnięcia korzyści majątkowej dla siebie lub osoby trzeciej, z czym nie musi się łączyć charakterystyczny dla zamiaru przywłaszczenia cel polegający na włączeniu cudzych składników majątkowych do majątku sprawcy lub postępowaniu z tymi składnikami majątkowymi w sposób charakterystyczny dla podmiotu, któremu przysługują określone prawa majątkowe. Po drugie - i co w perspektywie prowadzonej analizy ważniejsze - opis znamion typu czynu zabronionego z art. 286 $\S 1$ k.k. nie wymaga również, aby sprawca przestępstwa oszustwa działał w celu wyrządzenia szkody majątkowej. W perspektywie opisu znamion przedmiotowych oszustwa działanie w celu osiągnięcia korzyści majątkowej może, lecz nie musi skutkować wyrządzeniem po stronie pokrzywdzonego szkody majątkowej.

16 Ibidem, s. 305, teza 81 do art. 286 (teza dodana w porównaniu z poprzednimi wydaniami).

17 Zob. O. Górniok, D. Pleńska, op. cit., s. 418-419.

18 Zob. J. Bednarzak, op. cit., s. 96 n.; M. Dąbrowska-Kardas, P. Kardas, op. cit., s. 312 n.; T. Oczkowski, Oszustwo jako przestępstwo..., s. $27 \mathrm{n}$.

19 Zob. M. Dąbrowska-Kardas, P. Kardas, op. cit., s. 314. 
W konsekwencji, w perspektywie znamion strony podmiotowej oszustwa brakuje podstawy do stawiania wymagania, aby sprawca działał z zamiarem wyrządzenia szkody majątkowej. Co więcej, jeśli szkoda majątkowa nie należy do desygnatów znamion przedmiotowych oszustwa, to nie ma podstaw, aby wystąpienie takiego następstwa objęte było umyślnością ze strony sprawcy. Wyrządzenie szkody majątkowej jest okolicznością przedmiotową o charakterze obiektywnym, mającą znaczenie dla stopnia społecznej szkodliwości czynu, która może, lecz nie musi być objęta umyślnością ze strony sprawcy. Skoro zamiarem oszukańczym nie musi być objęte doprowadzenie pokrzywdzonego do wyrządzenia szkody majątkowej, to nie da się wykluczyć odpowiedzialności karnej za oszustwo w sytuacji, w której sprawca podejmie zabiegi oszukańcze w celu uzyskania korzyści majątkowej, jednocześnie nie obejmując zamiarem wyrządzenia szkody majątkowej po stronie pokrzywdzonego ${ }^{20}$.

Normatywna konstrukcja przestępstwa oszustwa jako typu z konkretnego narażenia dobra prawnego na niebezpieczeństwo, uzależniającego odpowiedzialność karną z art. $286 \S 1$ k.k. tylko i wyłącznie od spowodowania skutku w postaci wywołania stanu bezpośredniego niebezpieczeństwa dla mienia związanego z wystąpieniem zagrożenia interesów majątkowych podmiotu niekorzystnie rozporządzającego mieniem, w istocie rzeczy mieści w swoim zakresie szeroką kategorię zachowań przestępnych, różniących się od siebie zasadniczo stopniem społecznej szkodliwości in abstracto ${ }^{21}$. Za najistotniejszy element różnicujący stopień społecznej szkodliwości przestępstw oszustwa na poziomie generalno-abstrakcyjnym w związku ze wskazaniem cech pozwalających odróżnić od siebie ogólne kategorie zachowań charakteryzujących się różnym poziomem bezprawia należy uznać odwołanie się do kryterium szkodowości oszustwa. Wśród wymienionych w art. $115 \S 2$ k.k. okoliczności przedmiotowych istotnych dla wyznaczenia stopnia społecznej szkodliwości wskazuje się między innymi na „rozmiary wyrządzonej lub grożącej szkody", co jednoznacznie przesądza, że podstawową determinantą wyznaczenia stopnia bezprawia czynu jest ustalenie, czy z podjęciem tego zachowania związane było wyrządzenie szkody, czy tylko bezpośrednie niebezpieczeństwo jej spowodowania. Mając na względzie to, że art. $115 \S 2$ k.k. określa kryteria oceny stopnia społecznej szkodliwości konkretno-indywidualnego czynu zabronionego, za uprawnione należy uznać stwierdzenie, że wskazane w tym przepisie

${ }^{20}$ Przykładem takiego układu jest sytuacja, w której kredytobiorca wprowadzi w błąd bank odnośnie do swojej zdolności kredytowej w celu uzyskaniu kredytu, co do którego zakłada, że będzie go terminowo spłacał.

${ }^{21}$ Odnośnie do odróżnienia od siebie stopnia społecznej szkodliwości kategorii zachowań przestępnych od społecznej szkodliwości konkretnego czynu zob. między innymi T. Kaczmarek, Dobro prawne i spoleczna szkodliwość..., s. 289 n.; E. Plebanek, Materialne określenie przestępstwa, Warszawa 2009; R. Zabłocki, Pojęcie i funkcje społecznej szkodliwości czynu w prawie karnym, Warszawa 2007; A. Zoll [w:] Kodeks karny. Część ogólna, t. 1. Komentarz do art. 1-116, red. A. Zoll, Warszawa 2012, s. 50 n. 
determinanty oceny stopnia bezprawia czynu mogą mieć również znaczenie dla określenia różnic pomiędzy poszczególnymi kategoriami czynów zabronionych, realizujących znamiona jednego typu czynu zabronionego. Za oczywiste należy uznać stwierdzenie, że zasadniczo odmiennie należy oceniać stopień społecznej szkodliwości tych zachowań oszukańczych, które wywołały stan bezpośredniego niebezpieczeństwa dla mienia pokrzywdzonego, związany z zagrożeniem jego interesów majątkowych od tych, które skutkowały wyrządzeniem szkody majątkowej na mieniu.

W związku z tym w perspektywie realizacji znamion typu czynu zabronionego $\mathrm{z}$ art. $286 \S 1$ k.k. zabiegiem zupełnie oczywistym jest wyróżnienie dwóch zasadniczo różniących się stopniem społecznej szkodliwości in abstracto kategorii przestępstwa oszustwa. $Z$ jednej strony wyodrębnić należy odmianę przestępstwa oszustwa bezszkodowego, charakteryzującego się tym, że skutki podjęcia zachowań oszukańczych ograniczają się do wystąpienia bezpośredniego zagrożenia interesów majątkowych pokrzywdzonego w związku z faktem dokonania niekorzystnego rozporządzenia mieniem pod wpływem błędu. Cechą charakterystyczną oszustwa bezszkodowego jest to, że rozporządzenie mieniem nie skutkuje wyrządzeniem szkody majątkowej po stronie pokrzywdzonego, a skutki działań przestępczych ograniczają się do stworzenia stanu konkretnego narażenia na niebezpieczeństwo dobra prawnego $\mathrm{w}$ postaci mienia. $\mathrm{Z}$ perspektywy określenia generalno-abstrakcyjnie ocenianego natężenia bezprawia związanego z tą kategorią zachowań oszukańczych należy je, oczywiście, uznać za charakteryzujące się niższym stopniem społecznej szkodliwości niż analogiczne zachowania oszukańcze, prowadzące do wyrządzenia szkody majątkowej w mieniu. $Z$ drugiej strony wyróżnić trzeba odmianę przestępstwa oszustwa szkodowego, charakteryzującego się wystąpieniem skutku w postaci naruszenia dobra prawnego w postaci mienia ze względu na to, że niekorzystne rozporządzenie mieniem ze strony podmiotu wprowadzonego w błąd skutkuje nie tylko bezpośrednim zagrożeniem interesu majątkowego rozporządzającego mieniem, lecz ostatecznie doprowadza do wystąpienia po jego stronie szkody majątkowej. Oczywiście generalno-abstrakcyjnie wyróżniona kategoria przestępstw oszustwa szkodowego charakteryzuje się wyższym stopniem bezprawia od kategorii oszustw bezszkodowych. Warto jednak zwrócić uwagę, że wśród kategorii przestępstw oszustwa szkodowego można wyróżnić takie przypadki zachowań sprawczych, realizujących znamiona art. $286 \S 1$ k.k., które bezpośrednio skutkują wyrządzeniem szkody majątkowej w momencie dokonania niekorzystnego rozporządzenia mieniem ${ }^{22}$, od takich

22 Przykładem takiej odmiany szkodowego oszustwa jest wprowadzenie kupującego w błąd odnośnie do cech przedmiotu sprzedaży, wpływających na zawyżenie jego ceny, skutkuje szkodą majątkową po stronie kupującego obejmującą bądź wartość przedmiotu sprzedaży, jeśli doszłoby do ustalenia, że mając świadomość rzeczywistych cech przedmiotu, kupujący nie zawarłby umowy sprzedaży, bądź różnicę między wartością rozporządzenia a rzeczywistą wartością przedmiotu, 
przypadków, które w momencie dokonania niekorzystnego rozporządzenia mieniem tworzą bezpośrednie niebezpieczeństwo dla interesu majątkowego rozporządzającego, a dopiero w przyszłości może dojść do urzeczywistnienia się dalej idącego skutku w postaci wyrządzenia tym zachowaniem szkody majątkowej na mieniu $^{23}$. Nierzadkie w praktyce są przypadki, w których przestępstwo oszustwa ma z punktu widzenia kryterium jego szkodowości charakter złożony w tym sensie, iż zachowania oszukańcze mogą równocześnie prowadzić do wywołania w szerszym zakresie stanu bezpośredniego niebezpieczeństwa dla interesu majątkowego pokrzywdzonego, a jednocześnie do wyrządzenia w węższym zakresie szkody majątkowej na mieniu ${ }^{24}$.

Podział na oszustwa szkodowe i oszustwa bezszkodowe nie znajduje bezpośredniego zakorzenienia w opisie znamion przedmiotowych typu czynu zabronionego z art. $286 \S 1$ k.k. ze względu na akcentowaną wyżej okoliczność, iż na płaszczyźnie ustawowego opisu zachowań karalnych ustawodawca nie zdecydował się na wyróżnienie charakteryzującej się wyższym stopniem społecznej szkodliwości in abstracto kategorii oszustw skutkujących wyrządzeniem szkody majątkowej po stronie pokrzywdzonego. W systematyce Kodeksu karnego brakuje odpowiednika typu z art. $286 \S 1$ k.k., który zostałby ujęty jako przestępstwo skutkowe z naruszenia dobra prawnego, to jest typu uzależniającego odpowiedzialność karną sprawcy zabiegów oszukańczych od doprowadzenia do dalej idącego skutku w postaci wystąpienia szkody majątkowej po stronie pokrzywdzonego, co przekładałoby się każdorazowo na stwierdzenie, że dobro prawne w postaci mienia zostało naruszone, a nie jedynie narażone na niebezpieczeństwo ${ }^{25}$. Szerokie zakreślenie granic odpowiedzialności karnej z art. 286 § 1 k.k. w związku z ujęciem tego przestępstwa jako typu z bezpośredniego narażenia na niebezpieczeństwo jest o tyle specyficzne, że taki opis znamion przedmiotowych jest bardzo pojemny i pozwala pociągnąc do odpowiedzialności karnej za zachowania skutkujące „tylko” stworzeniem stanu bezpośredniego narażenia na niebezpieczeństwo interesu majątkowego pokrzywdzonego, związane z niekorzystnym rozpo-

jeśli doszłoby do ustalenia, że mając świadomość rzeczywistych cech przedmiotu, kupujący zawarłby umowę sprzedaży za niższą cenę.

23 Przykładem takiej odmiany szkodowego oszustwa jest wprowadzenie przez kredytobiorcę w błąd banku odnośnie do swojej zdolności kredytowej, co będzie skutkowało niekorzystnym rozporządzeniem mieniem ograniczającym się do stworzenia niebezpieczeństwa dla interesu majątkowego banku do momentu, w którym kredyt ten będzie regularnie spłacany, natomiast przyjmie postać oszustwa szkodowego, jeśli kredytobiorca przestanie spłacać kredyt.

${ }^{24}$ Ilustracją tego typu przypadku jest sytuacja, w której kredytobiorca wprowadzający w błąd bank odnośnie do swojej zdolności kredytowej dopiero po pewnym czasie zaprzestaje regulować raty kredytowe.

25 Analogicznie konstrukcyjnie zbudowane są typy szeroko rozumianych oszustw podatkowych z art. 56 k.k.s. i art. 76 k.k.s. Zob. P. Kardas [w:] P. Kardas, G. Łabuda, T. Razowski, Kodeks karny skarbowy. Komentarz, Warszawa 2010, s. 554, 674; oraz M. Dąbrowska-Kardas, P. Kardas, op. cit., s. 305, t. 81 do art. 286 (teza dodana w porównaniu z poprzednimi wydaniami). 
rządzeniem mieniem, które jednocześnie nie prowadzą do wyrządzenia szkody majątkowej w mieniu pokrzywdzonego, jak również za zachowania oszukańcze, doprowadzające do niekorzystnego rozporządzenia mieniem, a nadto skutkujące wyrządzeniem szkody majątkowej po stronie pokrzywdzonego. Ujęcie oszustwa jako przestępstwa materialnego z konkretnego narażenia na niebezpieczeństwo wydaje się zresztą zabiegiem celowym i mającym swoje głębokie uzasadnienie, albowiem pozwala uniknąć negatywnych konsekwencji wyróżnienia w systematyce przestępstw przeciwko mieniu dwóch odrębnych typów czynów zabronionych oszustwa w postaci oszustwa szkodowego oraz oszustwa bezszkodowego. Po pierwsze - szerokie ujęcie znamion przedmiotowych oszustwa jako przestępstwa konkretnego narażenia na niebezpieczeństwo, uniezależnionego na płaszczyźnie podstawy przypisania odpowiedzialności karnej od wykazania skutku w postaci wyrządzenia szkody majątkowej, uwalnia od wszelkich skomplikowanych i budzących wątpliwości interpretacyjne problemów łączących się z rozumieniem szkody majątkowej, w szczególności w zakresie wyznaczenia użytecznych na gruncie prawa karnego kryteriów ustalania wysokości szkody majątkowej oraz relewantnego dla szkody majątkowej punktu czasowego, na którą powinna zostać wyznaczona ${ }^{26}$. Po drugie - wskazanie szkody majątkowej jako skutku przestępnego typu statuującego oszustwo szkodowe miałoby konsekwencje na płaszczyźnie znamion strony podmiotowej, gdyż oznaczałoby konieczność wykazania, że wyrządzenie szkody majątkowej po stronie pokrzywdzonego objęte było umyślnością ze strony sprawcy. Po trzecie - wyróżnienie typów stanowiących szkodową i bezszkodową odmianę oszustwa prowadziłoby do konieczności stosowania konstrukcji zbiegu przepisów w tych wypadkach, w których zachowanie oszukańcze prowadziłoby do wywołania dalej idącego stanu bezpośredniego niebezpieczeństwa dla interesu majątkowego pokrzywdzonego niż szkoda majątkowa, która w wyniku takiego zachowania oszukańczego w rzeczywistości została wyrządzona.

26 Odnośnie do problemów wykładniczych związanych z pojęciem szkody majątkowej zob. między innymi J. Duży, „Szkoda” jak znamię przestępstwa z art. 585 kodeksu spótek handlowych (uwagi w kontekście odpowiedzialności karnej za działanie na szkodę spółek kapitałowych), „Prokuratura i Prawo” 2001, nr 4, s. 78; O. Górniok, O pojęciu „,korzyści majątkowej” w kodeksie karnym, „Państwo i Prawo” 1978, nr 4; eadem, Szkoda i szkoda pokrzywdzony jako znamiona przestępstwa nadużycia zaufania, [w:] Współczesne problemy procesu karnego i wymiaru sprawiedliwości. Ksiega ku czci Profesora Kazimierza Marszała, red. P. Hofmański, K. Zgryzek, Katowice 2003, s. 100 n.; P. Kardas, Szkoda majątkowa jako znamię przestępstwa nadużycia zaufania, „Prokuratura i Prawo" 1996, nr 7/8, s. 36 n.; J. Kowalska, Szkoda w rozumieniu art. 296 k.k. i kwestia ustalenia jej wysokości, „Przegląd Sądowy” 2001, nr 9, s. 65 n.; W. Kubala, Pojęcie szkody w kodeksie karnym, „Państwo i Prawo” 1975, z. 5, s. 76 n.; J. Skorupka, Szkoda majątkowa jako znamię przestępstwa $z$ art. 9 ustawy o ochronie obrotu gospodarczego, „Prokuratura i Prawo” 1997, nr 9, s. 69 n.; P. Zawiejski, Szkoda jako znamię przestępstwa działania na szkodę spótki, „Przegląd Sądowy” 2008, nr $7 / 8$, s. 59 n. 
Mimo że opis znamion przedmiotowych typu czynu zabronionego z art. 286 $\S 1$ k.k. nie daje podstaw do wyróżnienia szczególnej kategorii oszustw skutkujących wyrządzeniem szkody majątkowej, niemniej jednak silne normatywne wsparcie dla zróżnicowania prawnego charakteru odmian oszustwa szkodowego i bezszkodowego dają przepisy prawa materialnego, regulujące problematykę sądowego wymiaru kary. W świetle art. 53 § 1 i $\S 2$ k.k. w zw. z art. 115 § 2 k.k. rozważenie, czy konkretno-indywidualny czyn zabroniony realizujący znamiona art. $286 \S 1$ k.k. ma charakter oszustwa szkodowego, czy też oszustwa bezszkodowego ma zasadnicze znaczenie dla ustalenia stopnia społecznej szkodliwości czynu, a konsekwencji jest kluczowe dla wyznaczenia przez sąd granic adekwatnej i sprawiedliwej reakcji karnej na płaszczyźnie wymiaru kary. Chociaż okoliczność doprowadzenia przez sprawcę zabiegami oszukańczymi do wyrządzenia szkody majątkowej nie należy do zespołu znamion typu czynu zabronionego z art. $286 \S 1$ k.k. i nie ma bezpośredniego znaczenia dla przypisania sprawcy odpowiedzialności karnej za przestępstwo oszustwa, określenie szkodowego bądź bezszkodowego charakteru oszustwa, względnie określenia, w jakim zakresie zachowania oszukańcze doprowadziły do stworzenia bezpośredniego niebezpieczeństwa dla interesu majątkowego pokrzywdzonego w związku z doprowadzeniem do niekorzystnego rozporządzenia mieniem, a w jakim zakresie takie niebezpieczeństwo urzeczywistniło się w skutku dalej idącym, sprowadzającym się do wyrządzenia szkody majątkowej w mieniu, ma zasadnicze znaczenie dla ustalenia stopnia społecznej szkodliwości czynu i w konsekwencji bez ustaleń w tym zakresie nie jest możliwe przeprowadzenie racjonalnego procesu wymiaru kary ${ }^{27}$.

Na płaszczyźnie prawa karnego materialnego podział na oszustwo szkodowe i oszustwo bezszkodowe ma również znacznie na gruncie regulacji art. $295 \S 1$ i $\S 2$ k.k., przewidującej instytucję dobrowolnego naprawienia szkody, na podstawie której sąd może zastosować wobec sprawcy przestępstwa oszustwa dobrodziejstwo nadzwyczajnego złagodzenia kary, a nawet odstąpienia od jej wymierzenia. Regulacja art. 295 k.k. wprost znajduje zastosowanie wyłącznie do przypadków oszustw szkodowych, gdy sprawca oszustwa dobrowolnie naprawi wyrządzoną przestępstwem szkodę w całości lub w części. Prima facie art. 295 k.k. nie może znaleźć zastosowania do przypadków oszustw bezszkodowych, których cechą charakterystyczną jest brak wyrządzenia w wyniku zabiegów oszukańczych szkody majątkowej, a tylko stworzenie w ich wyniku bezpośredniego niebezpieczeństwa dla interesu majątkowego pokrzywdzonego. W pełni uzasadnione z punktu widzenia kryminalnopolitycznego jest to, że ustawodawca nie przewidział w wypadku przestępstwa oszustwa bezszkodowego klauzuli czynnego żalu w postaci analogicznej do tych, jakie występują w wypadku większości

27 Zob. M. Dąbrowska-Kardas, P. Kardas, op. cit., s. 305, teza 82 do art. 286 (teza dodana w porównaniu z poprzednimi wydaniami). 
przestępstw konkretnego narażenia na niebezpieczeństwo ${ }^{28}$. W celu uniknięcia negatywnych konsekwencji związanych z brakiem wyraźnej ustawowej podstawy do zastosowania nadzwyczajnego złagodzenia kary, a nawet odstąpienia od jej wymierzenia w razie uchylenia przez sprawcę dokonanego oszustwa bezszkodowego stanu bezpośredniego niebezpieczeństwa dla interesu majątkowego pokrzywdzonego, należy przyjąć, na zasadzie dopuszczalnej na gruncie prawa karnego analogii na korzyść sprawcy, wykładnię pozwalającą stosować do tego typu przypadków regulację art. 295 k.k. Takie rozwiązanie pozwala uniknąć niekonsekwencji systemowej, jaka występowałaby, gdyby uznać, iż z dobrodziejstwa przewidzianego w art. 295 k.k. mogą skorzystać dobrowolnie naprawiający szkodę sprawcy oszustwa szkodowego, a nie mogą z niej skorzystać sprawcy oszustwa bezszkodowego, którzy uchylili niebezpieczeństwo dla interesu majątkowego pokrzywdzonego, zanim została wyrządzona szkoda majątkowa w mieniu ${ }^{29}$.

Podział na oszustwo szkodowe i bezszkodowe ma swoje konsekwencje na płaszczyźnie prawa procesowego. W pierwszej kolejności należy wskazać, że wynikająca z art. 53 § 1 i $§ 2$ k.k. dyrektywa sądowego wymiaru kary, uzależniająca zakres reakcji karnej od stopnia społecznej szkodliwości konkretno-indywidualnego czynu zabronionego, prowadzi do wniosku, iż niezbędnym elementem postępowania dowodowego przeprowadzanego w toku postępowania karnego jest dokonanie ustaleń faktycznych pod kątem wykazania wszystkich tych okoliczności popełnienia czynu zabronionego, które mają znaczenie dla określenia stopnia bezprawia czynu, a w konsekwencji mają przełożenie na rozmiar orzeczonej za przestępstwo kary. W perspektywie celów postępowania karnego za równie istotne co ustalenie okoliczności faktycznych niezbędnych dla zweryfikowania podstawy przypisania odpowiedzialności karnej ze względu na przesądzenie realizacji znamion przedmiotowych i podmiotowych typu czynu zabronionego z art. 286 $\S 1$ k.k. jest dokonanie relewantnych ustaleń faktycznych dotyczących okoliczności mających znaczenie dla procesu wymiaru kary, w szczególności okoliczności istotnych dla ustalenia stopnia społecznej szkodliwości czynu. Postępowanie dowodowe prowadzone w sprawie, której przedmiotem rozpoznania jest zarzut dopuszczenia się przez sprawcę przestępstwa oszustwa, każdorazowo powinno być nakierowane na dokonanie ustaleń faktycznych, istotnych dla przesądzenia, czy in concreto oszustwo miało charakter bezszkodowy, czy też charakter szkodowy. Pomimo tego, że szkoda majątkowa nie jest znamieniem strony przedmiotowej typu czynu zabronionego z art. $286 \S 1$ k.k., każdorazowo postępowanie dowodowe w tego typu sprawach powinno być prowadzone nie tylko pod kątem wykazania,

28 Klauzule czynnego żalu, wyłączające karalność za dokonane typy czynów zabronionych z konkretnego narażenia na niebezpieczeństwo przewidują art. $160 \S 4$ k.k., art. 169 § 1, art. 176 $\S 1$ k.k., art. $220 \S 3$ k.k.

29 Zob. M. Dąbrowska-Kardas, P. Kardas, op. cit., s. 307, teza 84 do art. 286 (teza dodana w porównaniu z poprzednimi wydaniami). 
iż sprawcy można przypisać znamiona przedmiotowe i podmiotowe przestępstwa oszustwa, w szczególności można wykazać, że doszło do niekorzystnego rozporządzenia mieniem, lecz powinno być prowadzone także pod kątem weryfikacji ewentualnego faktu zaistnienia oraz rozmiarów wyrządzonej oszustwem szkody majątkowej. Konieczność poczynienia ustaleń dowodowych w tym zakresie determinują przepisy prawa materialnego, przy czym obowiązki takie wynikają nie tyle z konstrukcji znamion typu czynu zabronionego z art. 286 § 1 k.k., gdzie próżno szukać odwołania do znamienia wyrządzenia szkody majątkowej, ile z przepisów części ogólnej art. 53 § 1 i $~ 2$ k.k. w zw. z art. 115 § 2 k.k., mających zasadnicze znaczenie dla procesu wymiaru kary, w których świetle ustalenie rozmiaru szkody jest istotną determinantą określenia stopnia społecznej szkodliwości czynu in concreto $^{30}$.

Dokonanie ustaleń faktycznych, dających podstawę do uznania, że konkretno-indywidualny czyn realizujący znamiona typu czynu zabronionego z art. 286 $\S 1$ k.k. zalicza się do odmiany oszustwa szkodowego ze względu na to, że skutkował wyrządzeniem szkody majątkowej po stronie pokrzywdzonego, powinno również mieć przełożenie na opis czynu zarzucanego w akcie oskarżenia, a następnie czynu przypisanego w sprawcy w wyroku. Mimo że okoliczność wyrządzenia szkody majątkowej nie stanowi elementu opisu znamion przestępstwa oszustwa, kategorialna różnica w stopniu społecznej szkodliwości, jaka zachodzi między oszustwami szkodowymi i oszustwami bezszkodowymi, daje asumpt do twierdzenia, że dokonanie ustaleń faktycznych, wskazujących na wysokość wyrządzonej szkody, powinno znaleźć swoje przełożenie na opis czynu zarzucanego lub przypisanego sprawcy oszustwa. Wyróżnienie w ramach stanów faktycznych realizujących znamiona przestępstwa z art. $286 \S 1$ k.k. kategorii oszustw bezszkodowych oraz oszustw szkodowych znajduje na płaszczyźnie prawa procesowego przełożenie nie tylko na konieczność dokonania ustaleń faktycznych, pozwalających określić zakres niekorzystnego rozporządzenia mieniem oraz zakres ewentualnie wyrządzonej oszustwem szkody majątkowej, lecz także w związku z regulacją art. 413 § 2 pkt 1 i 2 k.p.k. nakłada obowiązek takiego skonstruowania przez oskarżyciela opisu czynu zarzucanego, a tym bardziej przez sąd opisu czynu przypisywanego, z którego jasno wynika, w jakim zakresie zachowanie oszukańcze doprowadziło do skutku przestępnego w postaci stworzenia stanu bezpośredniego narażenia na niebezpieczeństwo interesu majątkowego podmiotu niekorzystnie rozporządzającego mieniem, a w jakim zakresie zachowanie oszukańcze doprowadziło do dalej idących negatywnych skutków w sytuacji materialnej pokrzywdzonego w postaci wyrządzenia po jego stronie szkody majątkowej. W świetle poczynionych uwag uprawniona jest konstatacja, że wymóg precyzyjnego określenia w opisie czynu zarzucanego lub przypisanego zakresu wyrzą-

30 Zob. ibidem, s. 306, teza 83 do art. 286 (teza dodana w porównaniu z poprzednimi wydaniami). 


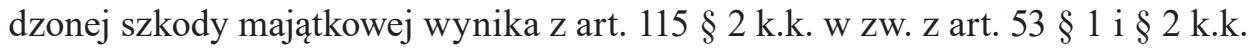
Opis czynu przestępstwa oszustwa szkodowego powinien zatem określać nie tylko wartość niekorzystnego rozporządzenia mieniem, do jakiego pokrzywdzony został doprowadzony na skutek zachowań oszukańczych, lecz także opis czynu powinien zostać poszerzony o wskazanie na wartość szkody majątkowej wyrządzonej przestępstwem oszustwa. Wymóg ten należy uznać za bezwzględny, jeśli jednocześnie konsekwencją przypisania odpowiedzialności karnej za oszustwo jest nałożenie przez sąd na podstawie art. $46 \S 1$ k.k. obowiązku naprawienia szkody. Oczywistą konsekwencją wskazanych regulacji procesowych jest konieczność wyjaśnienia w uzasadnieniu wyroku podstawy do rozstrzygnięcia zarówno w zakresie niekorzystnego rozporządzenia mieniem, jak i wyrządzonej oszustwem szkody majątkowej.

Przedstawione uwagi dotyczące znaczenia szkody majątkowej jako istotnej determinanty wpływającej na stopień społecznej szkodliwości czynu realizującego znamiona przestępstwa oszustwa pozwalają na postawienie ogólniejszego, jakby się wydawało - oczywistego, lecz często niedostatecznie sobie uświadamianego - wniosku, sprowadzającego się do twierdzenia, że na płaszczyźnie prawa materialnego istotne znaczenie z punktu widzenia adekwatnej reakcji karnej ma wykazanie nie tylko przesłanek odpowiedzialności karnej, zwłaszcza znamion przedmiotowych i podmiotowych typu czynu zabronionego, lecz także dokonanie ustaleń faktycznych dotyczących tych okoliczności, które mają znaczenie dla ustalenia stopnia społecznej szkodliwości czynu oraz okoliczności wpływających na wymiar kary. Stwierdzenie to ma istotne znaczenie na płaszczyźnie prawa procesowego, gdyż szerzej wyznacza zakres niezbędnego z punktu widzenia regulacji materialnoprawnych postępowania dowodowego w porównaniu z tym, które byłoby konieczne jedynie do zweryfikowania, czy zostały spełnione przesłanki odpowiedzialności karnej.

\section{Fraud causing damages and no-damage fraud as two distinctive types of the fraud offense}

Summary

This study contains a juridical analysis that presents the grounds for establishing differentiation with respect to the fraud offense regulated in Article $286 \S 1$ of the Criminal Code. The fraud offense may be divided into two distinctive types - fraud causing damages that results in suffering substantial material damages by an injured party, and so-called no-damage fraud that is limited in its effect to creating a state of exposure to direct danger of financial interest of an injured party. The article includes the analysis of substantive and procedural consequences of differences that arise between those two specified types of the fraud offense.

Keywords: fraud offense, fraud, Article $286 \S 1$ of the Criminal Code, substantial material damage. 